\title{
Meningkatkan Keterampilan Menulis Siswa Berbasis Media Blog
}

\author{
Febby Nabila Lestari \\ E-mail: febbynabila9@gmail.com \\ *Program Studi Pendidikan Bahasa dan Sastra Indonesia, Universitas Riau
}

\section{Pengantar}

Sejak tahun 2019, dunia digemparkan karena virus corona. Virus yang sudah memakan banyak korban itu menyebar secara cepat dan melumpuhkan segala aktivitas di dunia. Terlebih proses belajar mengajar ikut menjadi saksi. Seperti biasanya, pembelajaran dilaksanakan dengan tatap muka. Namun berbanding terbalik saat maraknya wabah covid-19. Pemerintah mengintruksikan agar pembelajaran dilaksanakan melalui daring, guna memutus mata rantai penyebaran covid-19. Daring adalah akronim dalam jaringan. Menurut KBBI Kemdikbud pusat yang artinya terhubung melalui jejaring komputer, internet, smartphone, dll. Jadi, daring merupakan kegiatan belajar mengajar guru, dosen, siswa, mahasiswa yang dilakukan secara online dengan menggunakan berbagai aplikasi pendukung seperti zoom meeting, google meet, google classroom, whatsapp, YouTube, dll.

Menulis merupakan salah satu dari keterampilan berbahasa, selain berbicara, menyimak, dan membaca. Menurut Tarigan (2008:3-4) menulis adalah proses dari kegiatan produktif dan ekspresif yang dibutuhkan ketika berkomunikasi secara tidak lengsung dengan memanfaatkan sistem tulisan, struktur bahasa, pemilihan diksi, dll. Menulis dikatakan produktif karena kegiatan menulis menghasilkan produk berupa tulisan, sedangkan ekspresif diartikan sebagai kemahiran untuk bisa mengungkapkan gagasan yang dimiliki siswa secara tertulis. Menulis menuntut seseorang memberikan efort, pengalaman, waktu, kesempatan, dan pengajaran langsung menjadi seorang penulis.

Inovasi terbaru weblog menawarkan kesempatan belajar secara online (Godwin, 2003). Blog merupakan media yang cocok untuk siswa mengunggah 
hasil dari tulisan-tulisannya. Media elektronik yang dapat menunjukkan perkembangan tulisan siswa dari waktu ke waktu. Dengan siswa mempublikasikan tulisan di blog internet, siswa memiliki kemunkinan bahwa karya tulisnya dibaca banyak orang dari berbagai kalangan. Hal tersebut dapat menimbulkan rasa tangung jawab yang besar, dan dapat mendorong siswa untuk lebih totalitas dalam menulis. Jika sebelumnya siswa menulis menggunakan pena, namun kali ini berbeda. Siswa menulis melalui media blog tanpa mengguakan pena karena bersifat online.

Berdasarkan pertimbangan-pertimbangan di atas, media blog diharapkan meningatkan efektifitas pembelajaran writing. Karena media blog memfokuskan kepada isi tulisan, serta menimbulkan umpan balik yang cepat karena hasil dari publikasi yang menuntut siswa untuk menulis lebih baik dan terstruktur. Kemudahan serta kedinamisan media blog dapat memfasilitasi pembelajaran yang aktif dan berpusat pada siswa. Dengan demikian penggunan media blog dapat mengasah kemampuan serta merealisasikan bakat dan minat peserta didik terutama pada aspek kemampuan menulis.

\section{Tindakan yang Dilakukan}

Guru adalah profesi yang tak lekang oleh waktu. Meski fisik akan terkikis dilalap waktu, namun ilmu serta pengabdian kepada negeri dalam bidang pendidikan akan tetap abadi. Guru adalah orang yang mampu memberikan pencerahan dan juga pemahaman baik moral maupun sprirtual kepada setiap insan. Guru adalah pendidik dan mengajari seseorang baik di jalur sekolah pendidikan formal, pendidikan dasar, dan pendidikan menengah. Perlu diketahui dan dipahami, bahwasanya guru yang mengajar dengan asal-asalan dan tidak profesional, beresiko menghasilkan generasi penerus yang rusak dan selanjutnya akan menghancurkan peradaban masyarakat. Maka dari itu, guru yang profesional mutlak diperlukan.

Sebuah ungkapan bijak "Guru digugu dan ditiru". Profesi guru identik dengan peran mendidik, membimbing, dan mengajar siswa. Hal ini menjadi poin 
penting bagi setiap orang yang mengemban profesi sebagai guru. Namun tugas guru bukan hanya pemindahan pengetahuan tetapi juga menanamkan nilai-nilai dari karakter dan akhlak peserta didik. Keberhasilan pendidikan dapat dinilai dari pemahaman serta prestasi peserta didik.

Guru mampu memberikan peran dan warna suatu bangsa dalam kontek pelaksanaan pendidikan sehingga patut menjadi perhatian (Mustafa, Hermandra, \& Zulhafizh, 2018). Maka tidaklah keliru, jika dikatakan guru sebagai pengajar berperan mentransformasi pengetahuan dan wawasannya kepada peserta didik, guru sebagai pendidik berusaha menanamkan nilai-nilai luhur kepada peserta didik, dan guru sebagai pemimpin tidak hanya melakukan pengajaran dan pendidikan tapi berusaha menciptakan iklim pendidikan dan pembelajaran yang kondusif dengan penuh tanggung jawabnya.

Tindakan yang dilakukan guru dalam proses pembelajaran menulis berbasis media blog yakni:

\section{a. Diklat Pembelajaran Daring}

Bagi yang terbiasa memanfaatkan teknologi dan memiliki pengetahuan, tentu dapat memudahkan dalam melaksanakan sistem manajemen pembelajaran daring. Dalam pembelajaran mesti dipahami bahwa siswa harus tetap aktif mengikuti pembelajaran walaupun tidak secara langsung.

Proses pembelajaran jarak jauh melalui internet atau dikenal dengan sebutan e-learning maupun distance learning yang semula tidak terlalu diperhatikan, saat ini menjadi kebutuhan. Lembaga pendidikan termasuk dalam dunia pelatihan untuk para pegawai. Sesuai dengan hasil penelitian Esthi bahwa untuk pembinaan dan pengembangan pegawai sudah saatnya melalui remote working (Bimanti Esthi, 2020). Penting bagi guru untuk mengikuti kegiatan yang diadakan di luar sekolah seperti diklat pembelajaran daring. Hal tersebut dapat menambah pemahaman mengenai pembelajaran daring yang belum dipahami sebelumnya. Guru perlu memiliki jalinan erat dengan teknologi. Sebab, ilmu yang didapat guru melalui diklat ataupun sosialisasi tersebut dapat direpresentasikan langsung kepada siswa melalui proses belajar mengajar. 


\section{b. Media blog}

Blog merupakan istilah yang berasal dari web blog secara bahasa bisa mengartikan "yang ditulis" dalam bentuk web log artinya "catatan". Dalam pengertian yang lebih formal blog merupakan website yang memiliki isi juga urutan waktu terbaik atas apa yang telah diposting. Postingan terbaru akan lebih dahulu ditampilkan, kemudian postingan yang lama. Media blog adalah wadah berbasis web untuk menulis dan sudah menjadi alternatif media yang tidak bisa dipandang sebelah mata. Dalam kenyataan nya blog banyak sekali dipakai oleh penggunanya. Melalui media blog siswa bisa mempublikasikan hasil karya tulisnya. Oleh karena itu, media blog sangat tepat digunakan guna meningkatkan kemampuan menulis siswa.

Semua siswa bisa membuat dan memiliki blog, yang dibutuhkan hanyalah sarana pendukung seperti smartphone, laptop, dan komputer yang harus terhubung dengan koneksi internet. Guru mempersiapkan materi pembelajaran menulis dan menjelaskan pembuatan media blog sebagai berikut:

1. Buka browser, kemudian ketik blogger.com

2. Jika kamu sudah mempunyai alamat email di gmail.com, kamu tidak perlu mendaftar dari awal. Karena dapat langsung masuk lewat email dan password. Untuk membuat blog pertama klik tombol buat blog (started blog).

3. Mengisi form berupa alamat email, nama panggilan, tanggal lahir, dll. Lalu verifikasi chapcha.

4. Mengisi data blog berupa judul blog, alamat url berupa nama seperti, mawarblogger.blogspot.com, dan pilih satu template yang kamu inginkan. Klik tombol buat blog.

5. Silahkan tekan tombol pensil jika ingin mengunggah tulisan.

\section{c. Mempersiapkan peserta didik}

Berbagai kebijakan muncul akibat adanya Covid-19. Aktivitas pendidikan dan pembelajaran menjadi persoalan, sebab ada banyak aktivitas yang tidak cukup secara teoritis tetapi juga praktis. Keadaan ini mengubah tindakan yang 
semestinya dilakukan secara langsung atau bertatap muka antara guru dan siswa terhenti dan terbatas. Penelitian Allo (2020) selama aktivitas mendukung, kegiatan belajar bisa berlangsung dengan baik. Sebaliknya, perangkat yang tidak memadai dapat memberikan pengaruh yang buruk terhadap hasil belajarnya. Artinya pendidik maupun peserta didik harus memfasilitasi dirinya agar bisa mengikuti dan melaksanakan pembelajaran secara daring.

Pada dasarnya proses pembelajaran tidak dapat terlepas dari guru dan siswa. Gage dan Berliner (dalam Suyono dan Hariyanto) melihat ada tiga fungsi utama guru dalam pembelajaran, yaitu sebagai perencana (planner), pelaksana dan pengelola (organizer) dan penilai (evaluator). Hal ini dikarenakan pendidik dan peserta didik bak benang yang saling bertaut. Proses pembelajaran harus mampu guru kembangkan dengan segenap potensi siswa. Perlu bagi guru ketika memulai pembelajaran dibuka dengan penuh semangat dan antusias. Karena energy baik yang guru tampilkan dapat dirasakan siswa. Guru juga perlu mempersiapkan model pembelajaran yang digunakan yang tentu saja sesuai dengan materi. Apalagi pada mata pelajaran menulis, guru harus memberikan tips dan juga arahan bagaimana menulis yang baik, serta memotivasi peserta didik untuk berkarya dengan semangat melalui tulisan. Mustafa, Hermandra, dan Zulhafizh (2019) ketika peserta didik terampil dengan sikap kreatif dan kritis maka lebih mudah baginya untuk menyelesaikan berbagai persoalan. Ia sudah mampu membaca berbagai peluang sehingga kualitas belajarnya tetap terjaga dengan baik.

\section{Sarana Pendukung}

Pembelajaran daring membuat guru untuk melek teknologi. Ketika guru sudah melakukan persiapan seperti ikut serta dalam diklat daring, ikut sosialisasi, membuat guru semakin mantap memanfaatkan fitur-fitur yang bisa digunakan saat pembelajaran menulis berbasis media blog:

\section{a. Smartphone}

Semaraknya teknologi pada masa kini menjadikan setiap orang tidak bisa lepas dari namanya barang elektronik seperti Smartphone karena fleksibel dan bisa 
di bawa kemana pun. Ponsel pintar adalah perangkat telepon genggam yang memiliki kegunaan serta berfungsi hampir sama dengan komputer ataupun laptop (M. Fitri Rahmadana ekonomi digital 2021). Smartphone menyediakan layanan akses bukan hanya digunakan untuk menelpon dan SMS saja, tetapi juga menyediakan berbagai fitur yang bisa digunakan pemiliknya. Seperti browser, chatting, video call, dll. Smarphone merupakan perangkat dasar dalam pembelajaran daring yang perlu dimiliki siswa sebagai pendukung belajar di rumah.

\section{b. Kuota dan Jaringan}

Kuota internet merupakan batasan pengguna pemakai internet yang terkoneksi melalui jaringan. Guru perlu memilah dan memilih platform pembelajaran daring sesuai dengan kemampuan siswa. Melalui koneksi internet atau jaringan merupakan hal yang utama agar terciptanya proses pembelajaran daring yang efektif tanpa adanya kendala. Tanpa adanya koneksi internet yang baik tidak akan ada interaksi secara langsung antara siswa dan guru. (Hamdani, et al., 2020). Begitu pentingnya koneksi internet ini bagi pembelajaran. Karena jika tidak, siswa akan kesulitan dalam mengikuti pembelajaran dengan baik hal itu dapat berdampak pada pemahaman para siswa atas apa yang telah dijelaskan guru. Kuota internet dan jaringan merupakan satu kesatuan yang saling berkaitan agar terciptanya proses belajar mengajar di era daring saat ini. Bak pondasi awal yang harus kokoh sebelum masuk ke tahap proses belajar.

\section{c. Google classroom}

Google classroom merupakan layanan online gratis untuk siapa saja yang ingin mendownload serta menggunakan platform tersebut. Google classroom memudahkan bagi peserta didik dan pendidik agar tetap terhubung dengan baik di dalam kelas maupun di luar kelas. Google classroom adalah pembelajaran yang dikembangkan oleh Google untuk sekolah atau institusi pendidikan lainnya yang bertujuan untuk menyederhanakan pembuatan pendistribusian dan penetapan tugas tanpa kertas. (M. Imaduddin, M.Pd., M.Si. 2018). Dalam penggunaan 
Google classroom di dalam nya juga terdapat google dokumen, Google Drive, Gmail/ Email. Guru bisa memberikan materi yang berkaitan dengan pembelajaran menulis dalam bentuk Microsoft word ataupun $p d f$, lalu mengirimkan ke Google Clasrrom agar dapat dibaca serta dipahami siswa. Sangat efektif dan efisien penggunaannya pada saat belajar mengajar melalui daring saat ini, karena pada penggunannya tidak perlu membutuhkan banyak kuota internet. Oleh karena itu google classroom wajib dimiliki oleh guru dan siswa.

\section{d. Zoom meeting \& Google meet}

Pembelajaran daring bisa diakses melalui berbagai macam situs dan aplikasi yang tersedia di internet dan yang paling banyak digunakan sebagai penunjang pembelajaran yakni Google meet atau zoom meeting. (Nurlina Guru dan Pembelajaran Inovatif Di Masa Pandemi Covid-19 2019). Zoom meeting adalah aplikasi yang dibuat oleh zoom video communication yakni sebuah perusahaan teknologi komunikasi yang berasal dari Amerika serikat. Sebenarnya platform zoom telah dirilis jauh sebelum terjadi pandemi, namun dengan terjadinya musibah yang menimpa seluruh penjuru negeri membuat platform zoom digunakan sebagai cara untuk mengatasi kebutuhan pembelajaran bertatap muka melalui kejauhan dengan menggunakan zoom meeting.

Zoom meeting dan google meet dari segi penggunaan serta fungsinya memiliki banyak kesamaan dan manfaat sebagai penunjang belajar mengajar $E$ learning. Guru bisa menampilkan media pembelajaran yang telah disiapkan dan menampilkannya pada bagian share screen agar siswa dapat melihat dengan saksama. Dalam proses belajar menulis guru bisa sesekali menggunakan zoom meeting atau google meet untuk berinteraksi secara langsung dan bertanya mengenai kendala apa saja yang dihadapi siswa saat menulis menggunakan media blog. Karena aplikasi zoom meeting berlandaskan seperti tatap muka, guru harus mengintruksikan siswa untuk menghidupkan kamera zoom pada saat pembelajaran. Dengan begitu suasana kelas mirip seperti belajar mengajar tatap muka, yang membedakan hanya situasi proses belajar dari rumah masing-masing. 


\section{e. WhatsApp grub}

Menurut Jubilee Enterprise (2012) WhatsApp adalah aplikasi chatting dimana para penggunanya dapat mengirim pesan berupa teks, gambar, suara (voice note) dapat juga disingkat dengan vn, lokasi, bahkan video. WhatsApp bersifat cross platform artinya pengguna whatsapp dari berbagai jenis tipe ponsel dari Android sampai appstore bisa menggunakan aplikasi WhatsApp dan akan tetap terhubung dengan yang lainnya. Terlihat jelas bahwa Whatsapp memiliki berbagai fitur-fitur yang menarik. Siapa sangka melalui media WhatsApp juga dapat dijadikan sebagai penunjang pembelajaran. Selain mudah dalam penggunaannya, whatsapp juga dinilai cukup aman karena memiliki sistem enkripsi pesan yang diklaim cukup baik. Dalam mengajar melalui aplikasi WhatsApp guru bisa membuat grup khusus dalam setiap kelas yang diampunya, melalui grup tersebut pembelajaran bisa diberlangsungkan. Tidak hanya itu, dari pengumuman, pemberian materi, instruksi tugas, pengembangan diri, kemudian mengenai tugas kelompok, dll. (Nurlina dalam Guru dan Pembelajaran Inovatif Di Masa Pandemi Covid-19 2019).

\section{f. Ebook/jurnal/artikel}

Buku elektronik atau ebook adalah sebuah buku yang bisa dibuka dengan menggunakan gawai yang harganya juga relatif terjangkau bahkan gratis. Sesuai dengan penjelasan dalam prosiding Seminar Nasional Pendidikan Program Pascasarjana Universitas PGRI Palembang tahun 2019, fungsi ebook yakni sebagai alternatif media belajar. Buku digital memberikan informasi secara menarik dan interaktif. Selain itu Buku digital adalah media berbagi informasi yang mudah disebarluaskan.ebook adalah buku dalam versi digital. Ebook atau elektronik book disebut juga digital book. buku digital menyajikan informasi berupa teks, gambar, video, audio, maupun bentuk multimedia lain yang bisa dibuka melalui laptop, komputer, dan smartphone. Guru dapat menggunakan ebook sebagai bahan materi tambahan yang akan dijelaskan kepada siswa.Selain ebook dan artikel, guru juga bisa menggunakan jurnal sebagai referensi pelengkap proses belajar mengajar. 


\section{Tindakan Solutif}

Pembelajaran daring memang tidak lepas dari berbagai kendala, seperti terbatasnya perangkat yang dimiliki siswa, akses internet, sampai pemahaman materi yang sulit dikuasi siswa. Hal tersebut mesti ditanggapi secara bijak oleh guru dengan ketersediaan menghadirkan pembelajaran yang interaktif bersama siswa. Oleh karena itu, muncul lah tindakan solutif yang bisa dijadikan sebagai penimbang saat proses pembelajaran secara daring.

Jika siswa tidak memiliki smartphone bisa meminjam/bergabung dengan teman. Berubahnya pembelajaran dari tatap muka menjadi daring memang menjadi tantangan tersendiri bagi para siswa, orang tua, sampai dengan guru. Meski begitu, bukan berarti pembelajaran ikut menjadi terhenti karena masa pandemi. Belajar mengajar akan tetap berjalan, yang berbeda hanyalah cara tempat saat pembelajaran berlangsung. Awalnya orang tua tidak memberikan fasilitas seperti smartphone/laptop untuk pembelajaran, namun situasilah yang merubah itu. Orang tua perlu menyediakan smartphone/laptop sebagai penunjang belajar anak. Tapi fakta di lapangan ternyata berbeda, tidak sedikit orang tua yang sedih karena tidak bisa memenuhi kebutuhan belajar mengajar anak saat pandemi. Jadinya anak tidak rutin mengikuti belajar mengajar. Oleh sebab itu cara agar anak tetap bisa belajar di masa pandemi yakni meminjam smartphone atau bergabung bersama teman sejawatnya untuk belajar bersama. Masalah dapat terpecahkan tanpa membebani orang tua.

Tindakan solutif yang bisa digunakan selanjutnya yakni menggunakan Warung internet. Warnet merupakan usaha yang dikelola oleh kelompok masyarakat atau individu yang memberikan pelayanan dalam bentuk jasa internet oleh penggunanya. Biasanya pengguna jasa warnet perlu mengeluarkan biaya sesuai dengan kebutuhan pengguna warung internet tersebut (M. Andika Yarobby 2018). Warnet bisa menjadi alternatif bagi siswa agar tetap mengikuti proses belajar guna meningkatkan kemampuan menulis berbasis media blog. 
Seperti yang sudah dijelaskan sebelumnya bahwa guru harus bijak dalam menggunakan fitur-fitur pembelajaran daring. Fitur zoom dan google meet tidak bisa dijadikan sebagai patokan pembelajaran menulis. Terlebih fitur tersebut bisa dikatakan boros kuota. Belum lagi kendala jaringan para siswa bahkan guru yang menyebabkan proses belajar mengajar menjadi terhambat. Oleh karena itu guru bisa mensiasati dengan membuat video pembelajaran lalu memposting di channel youtube yang di dalamnya berisi berbagai informasi mengasah keterampilan menulis, cara mendaftar dan menggunakan media blog, mengunggah tulisan di blog. Cara ini cukup efektif karena video yang telah diposting oleh guru, bisa menjadi media pembelajaran yang kapan saja bisa dilihat dan ditonton siswa.

Tindakan solutif selanjutnya jika peserta didik kebingungan dan tidak memiliki fasilitas untuk mencari ebook, jurnal, artikel yang relevan bisa dengan mencari buku diperpustakaan sekolah ataupun perpustakaan daerah. Menurut Kurniasih buku adalah buah pikiran yang berisi ilmu pengetahuan hasil analisis terhadap kurikulum secara tertulis. Buku disusun menggunakan bahasa sederhana, menarik, dan dilengkapi gambar serta daftar pustaka. Siswa bisa menjadikan buku sebagai referensi pemahaman untuk meningatkan keterampilan menulis.

Tindakan solutif yang terakhir jika siswa terkendala jaringan, guru senantiasa bertanya kepada peserta didik untuk terus terang atas permasalahan yang timbul saat pembelajaran. Sebagai guru perlu memberi dispensasi untuk waktu pengumpulan tugas. Kendala jaringan merupakan kendala yang tidak bisa dikendalikan guru ataupun siswa karena bukan ranah mereka. Dengan adanya keterbukaan dan kejujuran dapat tercapainya proses pembelajaran daring yang baik.

\section{Simpulan}

Profesi guru adalah pekerjaan mulia, setiap terobosan yang dipilih guru tentu membutuhkan pemikiran serta persiapan yang matang sebelum akhirnya direpresentsikan kepada siswa. Media blog hadir sebagai usaha guru untuk meningkatkan keterampilan menulis siswa. Menulis merupakan kegiatan positif 
yang dapat menghasilkan produk berupa hasil karya tulis. Terlebih jika siswa mengunggah tulisannya secara online melalui media blog. Hal tersebut dapat membuka peluang besar, karena tulisannya dapat dibaca oleh setiap kalangan dan bisa saja menimbulkan daya tarik serta minat pembaca. Oleh karena itu atas kemungkinan-kemungkinan yang bisa saja terjadi dapat menimbulkan rasa tangung jawab yang besar, dan dapat mendorong siswa untuk lebih totalitas dalam menulis.

\section{Referensi}

Asdani Kindarto, S. C. (2009). BLOGGING dengan BLOGGER. Jakarta: PT Elex Media Komputindo.

Asep Saepul Hamdi, E. B. (2014). Metode Penelitian Kuantitatif Aplikasi Dalam Pendidikan. yogyakarya: deepublish.

Dr. H. Dalman, M. (2016). Keterampilan Menulis. Depok: PT RajaGrafindo Persada.

Dra. Patni Ninghardjanti, M. C. (2020). Pembelajaran Multimedia Berbasis Mobile Learning. Banyuman, Jawa Tengah: Pena Persada Redaksi.

K., R. G. (2020). Pelaksaan Pembelajaran Daring di Era Covid-19. Jawa Tengah: Lutfi Gilang.

Mustafa, M. N., Hermandra, Zulhafizh. (2019). Teachers Strategies to Desaign Media to Implement Communicative Leaning in Public Schools. Journal of Educational Sciences, Vol. 3, No. 1, 13-24.

Mustafa, M. N., Hermandra, Zulhafizh \& Hermita, N. (2018). The Significance of Language Motivations Learning: Correclation Analysis. Advanced Science Letters, 24(11), 8080-8083.

Noor, M. (2019). Guru Profesional dan Berkualitas. Semarang, Jawa Tengah: ALPRIN.

Press, S. K. (2020). GURU DAN PEMBELAJARAN INOVATIF DI MASA PANDEMI COVID-19. Aceh: Syiah Kuala University Press.

S., R. H. (2008). Cara Cerdas Mengelola blog. Jakarta: PT Elex Media Komputindo. 
Thamrin Tahir, M. H. (2020). Perubahan Paradigma Pendidikan Dan Ekonomi Di Masa Pandemi COVID-19. Bandung Jawa Barat: MEDIA SAINS INDONESIA.

Zulhafizh, S. M. (2013). GURU: PROFESI YANG TAK LEKANG OLEH WAKTU. Dialog Interaktif Prefesi Kependidikan 1 (FKIP UNiversitas Islam Riau, 2(3), 1-11.

\section{*Data Penulis}

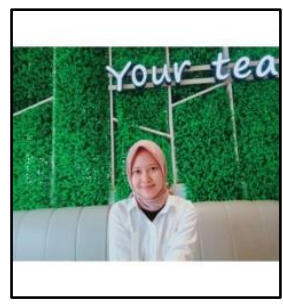

Febby Nabila Lestari, lahir di Pekanbaru, 3 Februari 2001. Pada tahun akademik 2019, Ia melanjutkan studi pada strata satu Jurusan Pendidikan Bahasa dan Seni di Program Studi Pendidikan Bahasa dan Sastra Indonesia FKIP Universitas Riau melalui jalur Bina Lingkungan. Pada saat ini beliau sudah semester 5 dan sudah menerbitkan berbagai macam karya buku seperti cerpen dan puisi. Beliau berharap untuk dapat menyelesikan studi dengan cepat di strata satu Jurusan Pendidikan Bahasa dan Seni di Program Studi Pendidikan Bahasa dan Sastra Indonesia FKIP Universitas Riau.

Kontak:

Hp/WA : + 6282171690031

Email : febbynabila9@gmail.com 